\title{
How Can Students Improve Their Reading Comprehension Skill?
}

\author{
Abbas PourhoseinGilakjani (Corresponding author) \\ Department of English Language Translation \\ Islamic Azad University, Lahijan Branch, Lahijan, Iran \\ 395, Opposite the EmamHosein Mosque, ValiyeAsr Street, Rudsar, Guilan, Iran \\ Tel: 98-142-623-2762_E-mail: a_p_g48@yahoo.com
}

\author{
NarjesBanouSabouri \\ Department of Linguistics, Payame Noor University, Tehran, Iran
}

Received: March 23, 2016 Accepted: May 31, 2016 Published: May 31, 2016

doi:10.5296/jse.v6i2.9201 URL: http://dx.doi.org/10.5296/jse.v6i2.9201

\begin{abstract}
Reading is an interactive process in which readers construct a meaningful representation of a text using effective reading strategies. Effective reading strategies are considered as significant skills that have received the special focus on students' reading comprehension proficiency. In this paper, the researchers define the term reading and reading comprehension, explain the types of reading, declare models of reading process, state theories of reading comprehension, review the effective strategies for reading comprehension, and finally mention findings of learners' reading strategies and their reading comprehension proficiency. The review of literature indicates that reading strategies play a significant role in improving the students' reading comprehension skill.
\end{abstract}

Keywords: Reading Comprehension, Kinds, Models, Theories, Strategies 


\section{Definition of Reading}

Anderson et al. (1985) defined reading as the process of making meaning from written texts. It needs the harmony of a lot of related sources of information. According to Wixson, Peters, Weber, and Roeber (1987), reading is the process of creating meaning that involves: (a) the reader's existing knowledge; (b) the text information; and (c) the reading context. Grabe (1991 as cited in Alyousef 2005) defined reading as an interactive process between readers and texts that result in reading fluency. Readers interact with texts as they try to extract meaning and there are different types of knowledge: linguistic or systemic knowledge (bottom-up processing) and schematic knowledge (top-down processing). Pourhosein Gilakjani and Ahmadi (2011) stated that the main goal of reading is to gain the correct message from a text that the writer intended for the reader to receive.

\section{Definition of Reading Comprehension}

According to RAND Reading Study Group (2002), comprehension is the process of eliciting and making meaning through interaction and involvement with written language. McNamara and Magliano (2009) emphasized that this process is a task of both reader and text factors that happen within a larger social context. Duke (2003) stated that comprehension is a process in which readers make meaning by interacting with text through the combination of prior knowledge and previous experience, information in the text, and the views of readers related to the text.

Kintsch (1998) and van Dijk and Kintsch (1983) defined reading comprehension as the process of creating meaning from text. The purpose is to get an understanding of the text rather than to acquire meaning from individual words or sentences. The outcome of reading comprehension is the mental representation of a text meaning that is combined with the readers' previous knowledge. This is called a mental model (Johnson-Laird, 1983) or a situation model (Kintsch, 1998). This model defines what has been learned (RAND Reading and Study Group, 2002). Keenan, Betjemann, and Olson (2008) expressed that reading comprehension needs the successful expansion and arrangement of a lot of lower-and higher-level processes and skills. Accordingly, there are many sources for possible comprehension break and these sources are different based on the skill levels and age of readers.

\section{Kinds of Reading}

There are two different kinds of reading. They are extensive reading and intensive reading.

\subsection{Extensive Reading}

There are different definitions for extensive reading. Hedge (2003) described it as skimming and scanning activities while Hafiz and Tudor (1989 as cited in Alyousef 2005) expressed that exposing learners to large quantities of meaningful and fascinating materials and activities will have a significant impact on the learners' knowledge of L2.A lot of researchers have shown great interest in extensive reading in the last years. A three-month extensive reading study was carried out by Hafiz and Tudor (1989 as cited in Alyousef 2005). The 
subjects of this study were Pakistani ESL learners in a UK school. The results obtained from this research indicated a significant advancement in the performance of the experimental subjects, particularly their writing skills. The subjects' improvement was somehow related to exposure to many lexical, syntactic, and textual features in the reading materials and the nature of the extensive reading materials.

Hedge (2003) declared that extensive reading differs based on learners' motivation and School resources. A highly motivated and well-trained teacher can certainly select appropriate materials and activities for their own learners. Hedge (2003) stressed that because extensive reading assists in expanding learners' reading skill, it should be incorporated into the EFL/ESL programmes provided that the chosen texts are valid and classified. In addition, extensive reading helps learners to gain their independency through reading either in class or at home.

According to Carrell and Eisterhold (1983 as cited in Alyousef 2005), extensive reading activities can be beneficial in aiding learners to become self-directed individuals who are searching for meaning provided that they are based on student-selected texts that learners will be interested in what they are reading. The process of choosing reading texts will be done according to content, level of difficulty, and length. Hedge (2003) mentioned the benefits of extensive reading as follows: Students can make their language proficiency, advance in their reading skill, become more independent in their learning, learn cultural knowledge, and expand confidence and incentive to continue their own learning.

\subsection{Intensive Reading}

In this type of reading, learners read a page to find the meaning and to be familiar with the strategies of writing. Through this reading, students can get fundamental practice in performing these strategies based on a series of materials. These strategies can be either text-related or learner-related. The first involves recognition of text organization and the second involves strategies such as linguistic, schematic, and metacognitive strategies (Hedge, 2003).

Yang, Dai, and Gao (2012) expressed that intensive reading is useful to develop reading comprehension. According to Waring (1997), intensive reading is very important for learning vocabulary and understanding how text is formed. Stahl (2003) found that there is relationship between intensive reading activities and language proficiency. According to Paran (2003), teachers need intensive reading to increase the three phases of learning called pre, during, and post-reading for better language readiness, retention, and activation strategies. Pollar, Durodo, Gonzalez, Simmons, Kwok, Taylor, Davis, and Simmons (2011) said that intensive reading is considered as a significant instrument for improving reading comprehension.

\section{Models of Reading Process}

There are three models for the second-language reading process: the bottom-up model, the top-down model, and the interactive model. 


\subsection{The Bottom-up Model}

Carrell (1989 as cited in Ahmadi \& Pourhosein Gilakjani 2012) said that the main focus of this model is the smaller units of a text like letters, words, phrases, and sentences. The reader reads all of the words in a phrase, or a sentence before understanding it. This model starts with decoding the smallest linguistic units, particularly phonemes, graphemes, and words and then makes meaning from the smallest to the largest units. The reader uses his/her background knowledge to the information that they find into the texts. There are some difficulties in this model. One of the drawbacks is that the reader is successful in reading when he/she deciphers the linguistic units and understands the connection between words. The reader is not able to keep in his/her memory the meaning of every word. The other difficulty is that it is not possible to connect one word to the other words.

\subsection{The Top-down Model}

Goodman (1967 as cited in Ahmadi \& Pourhosein Gilakjani 2012) stated reading as a "psycholinguistic guessing game" in which readers apply their previous knowledge to relate with a text and to connect these to new information found in the text in order to understand it. The readers do not read every word of a text but they focus on identifying the next words. They try to guess the meaning of words or phrases. Readers begin forecasting from the title of the reading text that permits them to restrict the scope of their reading. Then they assume the message the writer wants to transfer and change their hypotheses based on what they read in the text. Comprehension starts with higher levels of processing and continues to the application of the lower levels (Nuttall, 1996 as cited in Ahmadi \& Pourhosein Gilakjani 2012).

\subsection{The Interactive Model}

According to Rumelhart (1977), Nunan (1990), and Grabe (1991), the effective reading needs both top-down and bottom-up decoding. L2 readers can use top-down reading to make up for deficits in bottom-up reading. To obtain meaning, they apply their schemata to make up for the absence of bottom-up knowledge (as cited in Ahmadi \& Pourhosein Gilakjani 2012).According to Stanovich (1980 as cited in Ahmadi \& Pourhosein Gilakjani 2012), this model is based on information from various sources like orthographic, lexical, syntactic, semantic knowledge, and schemata. While readers are reading, decoding processes support each other. If they do not understand texts, they should apply their previous knowledge to help them. Readers who are dependent on top-down model use textual signs and inferthe meaning but they should make up for deficiencies like weaknesses in word identification and lack of effective bottom-up processing. This model results in the most effective processing of texts. Teachers should find reading instructions according to this model to boost L2 readers' skills. The mutual teaching method is a reading instruction that is based on the interactive model. It involves four principal reading strategies.

\section{Theories of Reading Comprehension}

There are three types of theories of reading comprehension. They are mental representations, content literacy, and cognitive processes. 


\subsection{Mental Representations}

Van Oostendorp and Goldman (1998) expressed that when a reader is reading a text, he can create a mental representation of the text that explains how the reader understands the text. A lot of researches supported the many levels of representation are included in constructing meaning. According to Kintsch (1998), when a reader is reading a text, three various levels of mental representation are created. They are the surface component, the text-base, and the situation model.

Kintsch (1998) continued that when the words and phrases and not the meaning of the words and phrases, are encoded in the mental representation, this is defined as the surface component of mental representation. The text-base indicates the meaning of the text and is composed of those parts and connections that are arose from the text itself without increasing anything that is not clearly identified in the text. A text-base can be made without any memory of the accurate words or phrases from the text. In a pure text-base, the reader applies previous knowledge to create a more perfect and consistent mental representation.

According to Kintsch (1998), the situation model is a structure that combines the text-base and the related features of the reader's knowledge. In order to create a text-base, some previous knowledge is required but this knowledge is a more general one that is necessary for decoding texts in general, while the previous knowledge in the formation of a situation model is more specific regarding the content of the text.

\subsection{Content Literacy}

Content literacy is the ability to read, understand, and learn from texts from a particular matter. There are three types of content literacy: general literacy abilities, content-specific literacy abilities, and previous knowledge of content. The general and the content-specific literacy abilities indicate some more general type of knowledge that does not hinge on the detailed content of a particular text. This knowledge is applied to make a text-base in the mental representation (McKenna \& Robinson, 1990). Previous knowledge of content is the knowledge that is related to the content of a particular text and is applied to make a situation model in the mental representation. For example, it is not obvious that mathematics makes a necessity for content-specific literacy abilities and the reading comprehension in mathematics hinges on more general literacy abilities and previous knowledge. It can be stated that the symbolic language in mathematics is the main cause for the need of content-specific literacy skills (McKenna \& Robinson, 1990).

\subsection{Cognitive Processes}

The application of syntactic and semantic rules together with the activation of more particular previous knowledge occurs automatically and unconsciously. Various cognitive processes are more or less conscious. Perception is defined as the highly automatic and unconscious processes. For instance, when we see a dog and directly know it as a dog; we are conscious of the outcome of the process but there isn't any active and conscious thought processes for this identification (Kintsch, 1992). Problem solving deals with active thinking when we want to remember the name of a person we see and know. Accordingly, when we read a text without 
having any difficulties in comprehending what we read, the process is related to perception than problem solving because the process of comprehending is unconscious. This is comprehension is located somewhere between perception and problem solving (Kintsch, 1992).

\section{Effective Strategies for Reading Comprehension}

There a lot of strategies for reading comprehension. These strategies are explained in detail in this section.

\subsection{Activating and Using Background Knowledge}

In this strategy, readers activate their background knowledge and apply it to aid them comprehend what they are reading. This knowledge consists of individuals' experiences with the world together with their concepts for how written text work, involving word recognition, print concepts, word meaning, and how the text is formed (Anderson \& Pearson, 1984).

Schema theory is very important in comprehension process (Anderson \& Pearson, 1984; Anderson, Reynolds, Schallert, \& Goetz, 1977). This theory is based on how people form and activate their previous knowledge. This theory explains that as persons learn about the world, they create a series of knowledge structures or schemas. These schemas develop and shift as the persons learn new information through experience and reading. For instance, a child's schema for dog can involve her or his comprehending of the family pet such as white, furry, and fun. When the child gets more experiences with a lot of dogs in different environments, the dog schema develop and can be improved. It can relate to other schema-kinds of dogs like colors of dogs; foods that dogs eat; places where they stay when the family is on holiday; and dangerous dogs.

Cognitive scientists stated that successful readers permanently relate their prior knowledge to the new knowledge they face in texts. Good readers activate their schema when they start reading. The first schema impacts how readers comprehend and react to a text (Pichert \& Anderson, 1977).Schemas are particularly significant to reading comprehension. When learners have knowledge of a text's organization, this can help them to understand better that text (Armbruster, Anderson, \& Ostertag, 1987).

\subsection{Generating and Asking Questions}

In this strategy, readers ask themselves pertinent questions in reading the text. This strategy assists readers to combine information, recognize main ideas, and summarize information. Asking appropriate questions permits successful readers to concentrate on the most important information of a text (Wood, Woloshyn, \& Willoughby, 1995). Creating relevant questions helps good readers to concentrate on difficulties with comprehension and to take the necessary actions to solve those problems (Pressley, Symons, McGoldrick, \& Snyder, 1995).

\subsection{Making Inferences}

Readers assess or draw conclusions from information in a text. In this strategy, writers do not always provide full information about a topic, place, personality, or happening. Instead, they 
provide information that readers can use to read by making inferences that integrate information of the text with their previous knowledge. Through this process, readers can improve their skills to make meaning. Being able to make inferences is an important factor for readers' successful reading (Anderson \& Pearson, 1984; Hansen\& Pearson, 1983).

\subsection{Predicting}

In this strategy, readers are able to gain meaning from a text by making educated guesses. Successful readers apply forecasting to make their existing knowledge to new information from a text to obtain meaning from what they read. Before reading, readers may apply what they know about a writer to forecast what a text will be about. The title of a text can operate memories of texts with the same content, permitting them to guess the content of a new text. During reading, successful readers can make predictions about what will occur next, or what opinions the writer will offer to support a discussion. Readers try to assess these predictions ceaselessly and change any prediction that is not approved by the reading (Gillet, \& Temple, 1994).

\subsection{Summarizing}

Readers combine information in a text to elaborate in their own words what the text is about. Summarizing is a significant strategy that allows readers to remember text rapidly. In this strategy, readers can be aware of text structure, of what is significant in a text, and of how opinions are related to each other. Effective summarizing of explanatory text includes things like condensing the steps in a scientific process, the steps of development of an art movement, or the episodes that result in certain important historical happenings. Effective summarizing of narrative text includes things such as connecting happenings in a story line or recognizing the elements that stimulate a character's activities and conduct (Honig, Diamond, \& Gutlohn, 2000).

\subsection{Visualizing}

Readers can make mental picture of a text to comprehend processes they face during reading. This skill shows that a reader perceives a text. Readers who form a mental image as they read are better able to remember what they have read than those who do not image (Pressley, 1976).Visualizing is very important when it is used for narrative texts. When readers read narrative texts, they can easily understand what is happening by visualizing the place, personalities, or operations of a plan. It can also be used for the reading of expository texts. Readers visualizing steps in a process or stages in a happening or forming an image that help them to recall some abstract ideas or significant names (Gambrell\& Bales, 1986).

\subsection{Comprehension Monitoring}

In this strategy, readers have the ability to know when they comprehend what they read, when they do not perceive, and to apply suitable strategies to make better their understanding. Successful readers know and check their thought processes as they read. Strategies that successful readers use to improve their understanding are called "fix-up" strategies. Particular 
repair strategies involve rereading, reading ahead, explaining the words by looking them up in a, or asking someone for assistance (Paris, Wasik, \& Turner, 1991).

Successful readers try to use different strategies to make meaning as they read. They do not use similar strategies; instead, they like to expand and practice those strategies that are beneficial to them. Moreover, they are very flexible in the application of their strategies, they change from strategy to strategy, and they apply various strategies with different types of texts (Paris, Wasik, \& Turner, 1991). The important point here is that successful readers can make good decisions about which strategies to apply and when to use them. A lot of students can gain from explicit instruction that teaches them to apply particular strategies for understanding a text. The other point is that particular comprehension strategies can be taught and learned and that their conscious use can help readers to ameliorate their comprehension (National Reading Panel, 2000).

\section{Previous Studies about the Relationship between Reading Strategies and Reading Comprehension Skill}

There is a positive relationship between learners' reading strategies and their reading comprehension skill. Brookbank, Grover, Kullberg, and Strawser (1999) indicated that the application of various reading strategies increased learners' reading comprehension proficiency. Golinkoff (1975) showed that poor readers read different texts similarly and did not try to learn through reading strategies. Ahmadi and Pourhossein (2012) represented that reading strategy has a positive effect on the reading comprehension proficiency of readers. Reading strategy ameliorated the reading skill of proficient and less proficient readers. Readers applied different reading strategies and knew what, when, how, and why to use them in their reading comprehension process.

Ahmadi and Pourhossein (2012) stated that learners who learn reading strategies try to recognize the main point of a paragraph, to elaborate unclear words, phrases, or sentences, and to summarize their reading. These strategies aid readers to solve their problems when reading texts and assess their planning and its result. Cziko (1980) stated that ESL/EFL lower proficiency learners hinge on orthographic qualities of the text words while advanced proficiency learners depend on syntactic, semantic, and discourse cues. According to $\mathrm{Gu}$ (1994), good and weak learners were different in using strategies in reading comprehension.

Chia (2000) said that readers intended to use more local reading strategies than global strategies. Parry (1996) expressed that her learners strongly applied bottom-up strategies than top-down strategies because it was related to their traditional approaches. The impact of reading strategies on the learners' reading proficiency was investigated by Su (2001). The results obtained from this study represented that readers' reading strategies are very useful to make better their reading skill. A study was done about reading strategy training by Song (1998).The findings indicated that reading strategy is one of the powerful factors in improving reading comprehension skill. The findings also revealed that foreign language reading should incorporate explicit strategy training. 


\section{Conclusions}

The findings of this study showed that reading strategies have a great impact on the students' reading comprehension ability. Students are not just passive receivers of information but they are active makers of meaning. Successful readers try to apply numerous skills to grasp meaning from the texts. Readers should be involved in the reading process by using different strategies to monitor their meaning. This study emphasized the idea that comprehension processes are influenced by a lot of strategies. All of these strategies work together to construct the meaning process easily and effectively. Based on the findings of this study, it is concluded that reading materials and activities should be very attractive to students in order to understand a text easily and they should be related to the students' proficiency levels. Teachers have a big responsibility to motivate their students in reading these materials, should be very sensitive to their learners' comprehension difficulties, and should help their learners to modify their views towards reading and have positive attitudes towards their reading activities so that they can better understand the different texts.

\section{References}

Ahmadi, M. R., \&PourhoseiinGilakjani, A. (2012). Reciprocal Teaching Strategies and Their Impacts on English Reading Comprehension. Theory and Practice in Language Studies, 2(10), 2053-2060. http://dx.doi.org/10.4304/tpls.2.10.2053-2060

Alyousef, H. S. (2005). TEACHING READING COMPREHENSION TO ESL/EFL LEARNERS. The Reading Matrix, 5(2), 143-154.Retrieved from http://www.readingmatrix.com/articles/alyousef/article.pdf

Anderson, R. C., \& Pearson, P. D. (1984). A schema-theoretic view of basic processes in reading. In P. D. Pearson, R.Barr, M. L. Kamil, \& P. Mosenthal (Eds.), Handbook of reading research (pp. 255-292). New York: Longman.Retrieved fromhttp:/hdl.handle.net/2142/31284

Anderson, R. C., Hiebert, E. H., Scott, J. A., \& Wilkinson, I. A. G. (1985). Becoming a Nation of Readers. Washington, D. C.: National Institute of Education.

Anderson, R. C., Reynolds, R. E., Schallert, D. L., \& Goetz, E. T. (1977). Frameworks for comprehending discourse. American Educational Research Journal, 14, 367-382. http://dx.doi.org/10.3102/00028312014004367

Armbruster, B. B., Anderson, T. H., \&Ostertag, J. (1987). Does text structure/summarization instruction facilitate learning from expository text? Reading Research Quarterly, 22, 331-346. http://dx.doi.org/10.2307/747972

Brookbank, D., Grover, S., Kullberg, K., \&Strawser, C. (1999). Improving student achievement through organization of student learning. (ED 435094).

Cziko, G. A. (1980). Language competence and reading strategies: A comparison of first and second language oral reading errors. Language Learning, 30, 101-116. http://dx.doi.org/10.1111/j.1467-1770.1980.tb00153.x 
Duke, N. (2003). Comprehension instruction for informational text. Presentation at the annual meeting of the Michigan Reading Association, Grand Rapids, MI.

Gambrell, L. B., \& Bales, R. J. (1986). Mental imagery and the comprehension-monitoring performance of fourth and fifth-grade poor readers. Reading Research Quarterly, 21, 454-464. http://dx.doi.org/10.2307/747616

Gillet, J. W., \& Temple, C. (1994). Understanding reading problems: Assessment and instruction (4th ed.). New York: Harper Collins.

Golinkoff, R. M. (1975). A comparison of reading comprehension processes in good and poor comprehenders. Reading research quarterly, 11, 623-659. http://dx.doi.org/10.2307/747459

Gu, P. Y. (1994). Vocabulary learning strategies of good and poor Chinese EFL learners. Paper presented at the 28th TESOL Convention, Baltimore MD. [ERIC ED 370 411]

Hansen, J., \& Pearson, P. D. (1983). An instructional study: Improving the inferential comprehension of fourth grade good and poor readers. Journal of Educational Psychology,75(6), 821-829. http://dx.doi.org/10.1037/0022-0663.75.6.821

Hedge, T. (2003). Teaching and learning in the language classroom. UK: OUP.

Honig, W., Diamond, L., \&Gutlohn, L. (Eds.). (2000). Teaching reading sourcebook for kindergarten through eighth grade. Novato, CA: Arena Press; National Reading Panel.

Keenan, J. M., Betjemann, R. S., \& Olson, R. K. (2008). Reading comprehension tests vary in the skills they assess: Differential dependence on decoding and oral comprehension. Scientific Studies of Reading, 12, 281-300. http://dx.doi.org/10.1080/10888430802132279

Kintsch, W. (1992). A cognitive architecture for comprehension. In H. L. Pick, P. van den Broek\& D. C. Knill (Eds.), Cognition: Conceptual and methodological issues,(pp. 143-163). Washington, DC: American Psychological Association. http://dx.doi.org/10.1037/10564-006

Kintsch, W. (1998). Comprehension: A paradigm for cognition. Cambridge, UK: Cambridge University Press.

McKenna, M. C. \& Robinson, R. D. (1990). Content literacy: a definition and implications. Journal of Reading, 34,184-186. http://dx.doi.org/10.1016/S0079-7421(09)51009-2

McNamara, D.S., \&Magliano, J. P. (2009). Towards a comprehensive model of comprehension. In B. Rose (Ed.), The psychology of learning and motivation (pp.297-384). New York, NY: Academic Press.

National Reading Panel. (2000). Teaching children to read: An evidence-based assessment of the scientific research literature on reading and its implications for reading instruction. Washington, DC: National Academy Press.

Paran, A. (2003). Intensive Reading EnglishTeaching Professional, 28,40-48.Cambridge: Cambridge University Press. 
Paris, S. C., Wasik, B. A., \& Turner, J. C. (1991). The development of strategic readers. In R. Barr, M. L. Kamil, P. B. Mosenthal, \& P. D. Pearson (Eds.), Handbook of reading research (Vol. 2, pp. 609-640). New York: Longman.

Parry, K. (1996). Culture, literacy, and L2 reading. TESOL Quarterly, 30, 655-92. ResearchBased Principles for Adult Basic Education Reading Instruction by The Partnerhsip for Reading-NIFL, National Institute of Child Health and Development, U.S. Dept. of Education, U.S. Dept. of Health and Human Services. http://dx.doi.org/10.2307/3587929

Pichert, J. W., \& Anderson, R. C. (1977). Taking different perspectives on a story. Journal of Educational Psychology, 69(4), 309-315. http://dx.doi.org/10.1037/0022-0663.69.4.309

Pollard-Durodola, S. D., Gonzalez, J. E., Simmons, D. C., Kwok, O., Taylor, A. B., Davis, M. J.,

\& Simmons, L. (2011). The effects of an intensive shared book-reading intervention for preschool children at risk for vocabulary delay. Exceptional Children, 77(2), 161-183. http://dx.doi.org/10.1177/001440291107700202

PourhoseinGilakjani, A., \& Ahmadi, S. M. (2011). The Relationship between L2 Reading Comprehension and Schema Theory: A Matter of Text Familiarity. International Journal of Information and Education Technology, 1(2), 142-149. http://dx.doi.org/10.7763/IJIET.2011.V1.24

Pressley, G. M. (1976). Mental imagery helps eight-year-olds remember what they read. Journal of Educational Psychology, 68(3), 355-359. http://dx.doi.org/10.1037/0022-0663.68.3.355

Pressley, M., Symons, S., McGoldrick, J. A., \& Snyder, B. L. (1995). Reading comprehension strategies. In M.Pressley\& V. E. Woloshyn (eds.), Cognitive strategy instruction that really improves children's academic performance. Cambridge, MA: Brookline Books.

RAND Reading Study Group. (2002). Reading for under-standing: Toward a research and development program in reading comprehension. Santa Monica, CA: Office of Education Research and Improvement.

Song, M. J. (1998). Teaching reading strategies in an ongoing EFL university reading classroom. Asian Journal of English Language Teaching, 8(1), 41-54.

Stahl, K. A.D. (2003). The effects of three instructional methods on the reading comprehension and content acquisition of novice readers.Paper presented at the meeting of the National Reading Conference, Scottsdale, AZ.

Su, C. (2001). Evaluation of reading skills applied in the first-year college English reading course. Papers presented at the Tenth International Symposium on English Teaching. Taipei: Crane. 
Van Dijk, T. A., \&Kintsch, W. (1983). Strategies of discourse comprehension. New York: Academic Press. http://dx.doi.org/10.1177/1461445606059565

Waring, R. (1997). Graded and Extensive Reading-Questions and answers. The Language Teaching on line. Available: http://jaH-publications. Ogr/ttt/files//79/may/Waring. Html.

Wixson, K., Peters, C., Weber, E., \&Roeber, I. (1987).New directions in statewide reading assessment. The Reading Teacher, 40(8), 749-755.

Wood, E., Woloshyn, V. E., \& Willoughby, T. (1995). Cognitive strategy instruction for middle and high schools. Cambridge, MA: Brookline Books.

Yang, W., Dai, W.,\&Gao, L. (2012). Intensive Reading and Necessity to Integrate Learning Strategies. English Language and Literature. 2(1), 55-63. http://dx.doi.org/10.5539/ells.v2n1p112 